
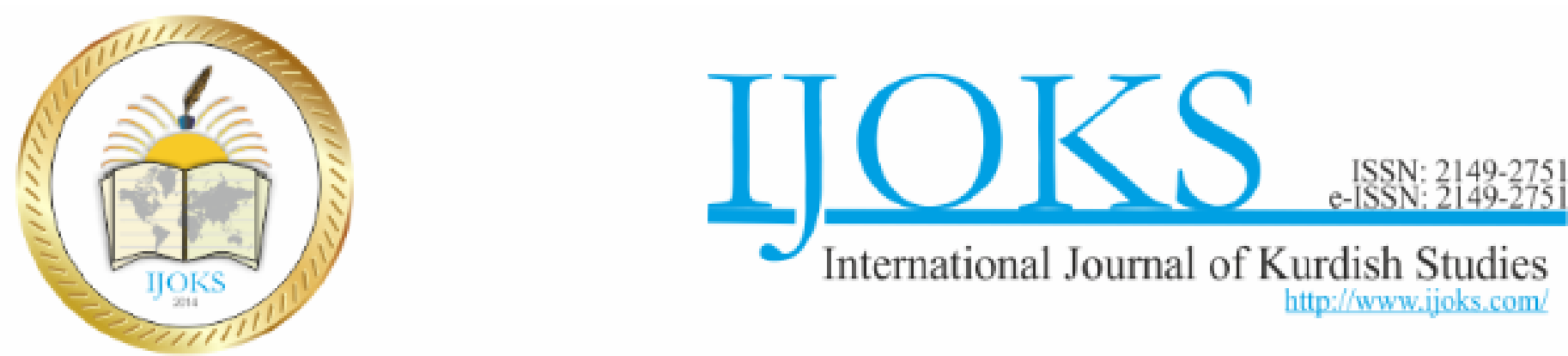

\title{
Article
}

International Journal of Kurdish Studies

5 (2), pp. $373-392$

http://www.ijoks.com

\section{The Burden of Colonialism and Alienation in the Modern Kurdish Novel}

\section{Chiad ABDULKARIM ${ }^{1} \&$ Ismael SAEED ${ }^{2}$}

\author{
Received: Feb 24, $2019 \quad$ Reviewed: Mar 14, $2019 \quad$ Accepted: Mar 24, 2019
}

\begin{abstract}
Focusing on the impact of colonialism and how its forces are reflected in the modern Kurdish novel, it becomes apparent that such forces are still greatly at work in Middle Eastern regions with Kurdish populations. It is apparent that sophisticated physical, cultural, and economic means are implemented in an ongoing process that denigrates stability, prosperity, and peace. Moreover, on closer examination, it becomes clear that colonialism has a fourfold effect: Firstly, colonialism causes internal displacement, as illustrated in the two recent novels by Iraqi Kurdish writer Gharbi Mustafa entitled When Mountains Weep: Coming of Age in Kurdistan, and What Comes with the Dust Goes with the Wind. Secondly, it prompts an inner psychological conflict, which experience is illustrated in the novel Dawiya Şervanekî [The End of a Warrior], an earlier novel by Ismet Badal, Also, an Iraqi Kurdish writer. Thirdly, it arouses a thirst for the traditional and serves as a spur to the quest for traditions - a narrative of the novel Hüyükteki Nar Ağacı [The Pomegranate on the Knoll] by Yashar Kemal, also a Turkish-Kurdish writer. Fourthly, it is apparent that the above dominant narratives in Kurdish modern novels have triggered a response among the Kurdish populations.
\end{abstract}

Keywords: Kurdish novel, alienation, colonialism, Turkish novel, internal displacement, Kurdish traditions, Yashar Kemal, Ismet Badal, Gharbi Mustafa, modern Kurdish literature, Iraqi novel

\section{Recommended citation:}

Abdulkarim C. \& Saeed I. (2019). The Burden of Colonialism and Alienation in the Modern Kurdish Novel. International Journal of Kurdish Studies 5 (2), 373 - 392 DOI:

\footnotetext{
${ }^{1}$ Correspondent Auther: Department of English, University of Zakho, KRG, Iraq, E-mail: chiaa2004@gmail.com, ORCID : 0000-0002-9885-747X

${ }^{2}$ Department of English, College of Languages, Salahaddin University, KRG, Iraq, E-mail: superboy1961@gmail.com,
} 


\section{Introduction}

Colonial forces are still greatly at work in territories and regions inhabited by Kurds of the Middle East. A comparison can be drawn with the invasions of Britain in medieval times, and the efforts of different nations and tribes to establish their own codes of law and order in vanquished territories. In our modern times, something similar could be said of the Kurds only that there is an updated and more sophisticated means of implementation where physical, cultural, economic, and colonial invasions are ongoing processes and populations are deprived of stability, prosperity and peace. This ongoing process impacts at four levels. Reflected in Gharbi Mustafa's two novels When Mountains Weep: Coming of Age in Kurdistan, and What Comes with the Dust Goes with the Wind, written in English, is internal displacement and conflict; reflected in Ismet Badal's novel Dawiya Şervaneki, written in Kurdish(2005), is the experiencing of an inner psychological conflict; and, reflected in a novel originally written in Turkish, Hüyükteki Nar A ̈̆acı by Yashar Kemal (1923-2015), is the arousal of a thirst for traditions. In all these novels, the quest for traditions is accompanied by a search for an alternative that looms on the horizon - such as a homeland in a diaspora; this is where the writer finds himself with a mission to reconstruct what has been lost and what is being lost. He must remain loyal to his mother tongue, and provide a strong sense of connection to his culture. This theme interacts with the dominant narratives in what might be called a "novelistic novel." We also find the construction of a homeland on paper in the opening and third chapter of Mehmed Uzun's novel written in Kurdish: Mirina Kaleki Rind [The Death of a Nice Oldman]. It was originally published in 1987 and republished by Itihaki in 2007.

In the light of the above, and by way of response to the external and dominant forces of today's world, those nation-states that are regional players, this article will first consider Gharbi Mustafa's two novels When Mountains Weep: Coming of Age in Kurdistan (2013), and What Comes with the Dust Goes with the Wind (1 $1^{\text {st }}$ ed. 2016).

As a literary genre, the novel has influenced the lives of multitudes of readers worldwide. Moreover, since the rise of the feature film industry this genre has become the primary source for the writing of screenplays. As a result, writers with diverse backgrounds have attempted to express themselves especially English, a language that targets not only an international readership, but also prominent film producers who do well on the commercial scene. Recently, there has been a limited number of Kurdish authors writing their literary works in English. Such is the case of Gharbi Mustafa who has published two novels in English so far, the aforementioned When Mountains Weep, and What Comes with Dust Goes with the Wind.

\section{Remarks Regarding Mustafa's First Two Novels}

The voice of the protagonist in When Mountains Weep personalizes the voice of a whole nation addressing an international readership, which is to say, addressing people from diverse backgrounds and cultures. In order to reliably voice and give an authentic account of events taking place during a specific era, Mustafa chooses to write in the genre of historical fiction. 
The novel is set in the second half of the twentieth century in Iraq. It is an era in which people were subjected to both psychological and physical hardship. We find the family of the protagonist Hamko urging him to pursue his studies, regardless of the risk - "Grandpa stroked my hair with his long, smooth fingers and explaining, said: Hamko, you should be proud. After all, you are the first boy in our family to go to school" (Mustafa, 2013, p. 8). If Hamko had refused to carry out his family's wishes, he would have been obliged to serve in the Iraqi military.

Thus, the writer opens his novel with an adult sharing his childhood experiences through flashbacks that describe himself as a boy witnessing the suffering inflicted by the Ba'ath Party, and their methods. The writer clearly wants to inform his readers about the extraordinary abuses the governmental establishment inflicts - on a daily basis. The educational system is presented as mostly feeding the children at school with too many "whats" - what Hamko is allowed to speak, what he is allowed to see, what he is allowed to think, what he is allowed to touch, and what he is allowed to write, with not even one "how."

The writer tells of the way in which the protagonist decides to breakdown the set of rules designed for the individual by the academic mentality, academics working in the interest of the their own group, in a country that had been and was in a state of constant internal struggle due to the existence of the domination of one dogmatic totalitarian system. It is a country that fails to fairly treat its multitude of ethnicities, religions and identities. One cannot but remember that Mustafa had previously written a drama in English, a stage play that deals with the life of a Kurdish female figure, an undergraduate student at Baghdad University. She bravely stands up for her nation's cause. The play is entitled Layla, The Kurdish Bride. In regard to these of his writings, I can affirm that the author has managed to take into account a nation's traumatized background and then to successfully fictionalize representative characters for his readers or audience, as the case may be. Hamko, the hero of When Mountains Weep, is a "kid" who is supposed to have fun, to play in a playground, to feel close to a family who sympathize with his dreams. But, ironically nothing is like that. Gibbs and Colston in their book Irony in Language and Thought define an ironic situation as being "a situation in which events are in opposition to what was, or what might naturally be expected, or a contradictory outcome of events as if in mockery of the promise and fitness of things " (p. 467). In order for the school to ensure that Hamko is silent and submissive, he is abused, banned from using his mother language (and later, regardless, he will be obliged to serve in the military). Hamko, the child as the voice of the nation weeps - he implicitly and explicitly rejects the norms imposed on him:

The teacher entered the classroom holding a book in one hand and a long wooden stick in the other... When one of the boys failed to repeat the words correctly, she hit him twice on the palms of his hands with the stick, and the boy started to cry. (Mustafa, 2013, p. 6)

Hamko's journey continues in a country torn by internal conflict and external war as well, a country already at war with neighboring Iran. The media manipulates the news so as to persuade people of the rightness of the war. "One hot summer day I was riding in a bus, 
listening to the vehicle's radio broadcast songs glorifying the war with Iran”(Mustafa, 2013, p. 62).

In all fairness, it should be mentioned that in the majority of Iraqi educational institutions of the times, corporal punishment was usually in place - to give the devil his due, this was regardless of ethnicities. However, Hamko, the little boy from the hillside, could hardly know that. And how could he be expected to disregard the inflicted pain? Kurdish children, alongside all other children, in the Iraqi schooling system, got acquainted with pain rather than pleasure at school. It is that which counts; it is that which sticks to mind. In sarcastic terms, the writer Mehmed Uzun supplies us with another account of a childhood experience that absolutely confirms this point:

The first lesson goes back to 1960, the year I was seven. On a hot, clear day at the end of summer, the very day on which, dressed in new clothes from head to foot, I was beginning grammar school, I received a violent slap in the face in the guise of a lesson on the importance of language and words (Uzun, 2003, p. 25).

Besides political issues surrounding the events of the 70s and 80 s of the last century, Uzun's novel is a love story depicting a country where love struggles to exist. Honor killing is commonly practiced as a means of mundane salvation for society at large: "The second man placed a bloody handprint on the upper part of the metal house gate as a badge of honor before he also disappeared into the house"(Uzun, 2013, p. 55).

Like Uzun, in both his writings and novels, Mustafa dwells on the subject of pain and suffering, be it internal or external. Uzun admits that writing is a means to liberate oneself from two types of pain: the pain of the suffering and the pain of the lies. He writes:

Due to a reasoning that had nothing to do with me, I came into the world as a Kurd. And, since then my life has been marked by two things: suffering and [the joy of] living. And, one can say that whatever are my faults, the forty-seven years of my life have been entirely devoted to a struggle designed to free me from those two evils (Uzun, 2003, p. 25).

Mustafa's protagonist, now a university student, is in love with his classmate Pari. The two share some joyous moments, as well as some of their most miserable moments., but Hamko finds it difficult to express his feelings.

I have been avoiding this conversation for months, since I was afraid it might ruin our wonderful friendship. I didn't expect to feel this way for so long, but the fact is, there hasn't been a day since we met that I haven't thought of you. I think you are amazing. (Mustafa, 2013, p. 99).

Hamko ponders the unjust circumstances that force him to participate in a war against also a Kurdish population. Aside from being a love story, and a story of escape from the evils of the protagonist's own familial home and homeland, and a story of the return to a homeland where 
there remain challenges and hardships - in his multi-layered narrative, Mustafa deals with the story of a collective who bear the burden of oppression.

In the external world of Mustafa's story, events of 2014 saw another of ISIS's invasions. As is known, ISIS employed not only weaponry to impose their conquests, but other means as well to ensure their soldiers' domination of ethnic groups of the region - which included of course, the Kurds. A major method of ISIS' invasion was what could be called a "cultural invasion." This method has already been experienced by Kurdish populations for about one hundred years. It is thus a well-known method in which neighboring populations and /or a government impose their own culture in an attempt to include populations in the dominant culture. These forces seek to obliterate features such as the language, music, art, and religion in favor of social fabrics that at variance with the original lifestyle of indigenous populations. Together with economic hardship, combined with the all-round oppression that has led to the internal displacement of civilian populations, the result has even been that civilians seek settlement in countries where they are strangers. It is at this point that Mustafa publishes his novel What Comes with the Dust Goes with the Wind. Here, the author depicts certain forces that contribute to the creation of chaos in a region inhabited mainly by Yezidi Kurds.

The novel What Comes with the Dust is narrated in the third person. Here, we have an omniscient narrator with unlimited access to characters' thoughts and feelings. "Thoughts whirled in her head, and her heart pumped faster than the swing," Mustafa writes (2017, p. 6). The novel opens with protagonist's wedding day. Nazo is in the bathroom seemingly wishing to commit suicide. This pessimistic scenario is followed by a prolonged and creative flashback. Apparently Nazo's parents had gone on believing in the tradition of arranged marriage despite that as a result, Nazo's siblings including a sister who is deaf, suffer from congenital disabilities. Her parents had already arranged her own marriage to a cousin. Nazo's predicament will be a driving force behind events of the novella: Will the persona Nazo resist this practice or embrace silence?

In the above flashback, we are introduced to a frantic young girl named Nazo, a young girl who had recently suffered under ISIS. Then, the protagonist Azad steps into the picture. We see that these young people face two similar psychological barriers - a trauma heralding from their own Kurdish traditional practices, as well as the displacement imposed on them by armed groups in the region. However, their intimacy becomes a source of hope, and eventually leads them to migrate to another country where co-existence prevails as an alternative to their native land. Azad is a young Yezidi teacher, raised by his grandfather. When he falls in love with Nazo, his grandfather encourages him to search for a place where love is acceptable and there is no associated fear. The importance of love is highlighted when the writer Mustafa puts words into the mouth of the grandfather that are impassioned and poetical: "The love in your heart ought to silence the voices in your mind. Go ahead. If love compels you to cross the Aegean, then bury your fears beneath its waters. Only excuses confuse our lives, not the reality"(Mustafa, 2017, pp. 12-13). Mustafa also meta-comments on the theme of love - " no one is immune to love, the most ancient virus in human 
history"(Mustafa, 2017, p. 15). Such comments contribute to the creation of a strong narrative in modern literature.

The present writer suggests that Mustafa's novel functions on two levels. From the outset, the reader becomes acquainted with the author's epigrammatic style of writing. Azad is afraid of water: "The other fishermen's children mocked Azad, calling him the blue cat because he screamed in panic each time Grandpa dragged him into the boat to teach him to fish"(Mustafa, 2017, p. 11). Since water symbolizes the source of life in general and specifically for Azad's grandfather, Hassan Seydo strongly believes in fishing and he is willing to persuade his grandson to quit school for the sake of fishing: "Grandpa never liked school. He thought people could learn more from a fish than from another human. However, as the years passed, his curse turned into a prophecy, and Azad became a school teacher" (Mustafa, 2017, p. 11). Following this, there is yet another epigram, one related to the contrastive voices used in the novel, and so on.

The epigrammatic style was previously used by Uzun in his above novel Mirina Kalekî Rind. The narrator in this novel, in Uzun's poetical style, justifies the epigrammatic, as follows:

Writing is a journey, a kind of journey. It is a journey through waves of the sea. Writing is a journey filled with experiences. One should fight the waves so as to find one's path, so as to take the righteous path. So as to re-live experiences already lived. . . one should accept this fight (Uzun, 2007, p. $68)$.

In the case of his protagonist Azad, Mustafa uses the metaphor of the waves of the sea on two levels, firstly to function as a stylistic device that ornaments - Aristotle in his Art of Rhetoric says that metaphor is above all what gives perspicuity, pleasure, and a foreign air (Aristotle, 2019 , p. 355). Secondly, he uses the epigrammatic cognitively to make readers understand the author's own experiences. Accordingly, metaphor helps the reader access abstract ideas.

The utterances of the grandfather when Azad is an adult contrast with what his grandfather told him when he was at school: "As grandpa fixed the schoolbag on the boy's shoulders, Azad turned and put his arms around grandpa's left leg then burst into tears. Grandpa patted his head, saying: Go boy. You do not want to miss your first class" (Mustafa, 2017, p.12). Love for Nazo provides life with a daring aspect for Azad. In pursuit of happiness, Azad is now willing for the first time to encounter the boat and the sea.

As an aside - In English literature, epigrammatic writing is considered a well-established narrative style, Oscar Wild's narrative serving as an example. A prime intention of novels, in the present writer's estimation alongside other important features, is that the novel should be accessible and entertain. In the case of epigrammatic writing, readers find it easy to extract certain paragraphs or quotations for their specific individual use. Secondly, as a narrative technique, a meta-comment could indicate a change in a character's attitude toward a specific subject matter. In face to face conversation, I am referring to real-life situations in this instance, people find it easy to notice a change in another person's attitude while talking; it 
could be through a change of facial expression or a movement of the hand or a shift in posture or other body language. However, for a similar change in attitude and change of mind to be apparent in a written text, meta-comment seems to be useful. Moreover, the meta-comment aptly creates a connection between the narrator of the story and the characters. Although the work on hand is a work of fiction, the use of meta-commenting in the novel serves to function very well in presenting the actuality of the insurmountable obstacles the Yezidis faced after the ISIS invasion of their villages in the mid-2014s.

To return to the story-line, Mustafa's What Comes with the Dust presents two types of love in an ISIS-controlled village. Omed's love for Nazo is one-sided. He is more infatuated with her than being truly in love. In order to convince that his love is genuine, Omed dramatically cuts himself with a razor. This particular act symbolizes certain traditional practices of youthful residents in the Kurdistan region and are probably common elsewhere but manifest in various ways. It could be said that such practices probably indicate that the power of immaturity is dominant over the power of reasoning. When unguided teenagers reach a specific age, they tend towards risk-taking and tend towards doing things that cannot be justified rationally like what Omed does. As the author of a novel, Mustafa portrays Omed as being unready to abandon his delusional one-sided love. The present writer believes that responsible members of the community should seriously consider Mustafa's message, and instruct their youth accordingly. Once at a specific age, these youngsters naturally tend to take risks. Omed, who seems that he has not been instructed wisely, could jeopardize his life without realizing the terrible consequences that the future holds for him.

On the other hand, Azad's love for Nazo represents a modern view of love but more importantly, in context, his love is considered as disrespect for rituals in the Yezidi community. It is true that he initially made love with Nazo having her full approval. However, this was done out of wedlock. In a community where traditions reign over modern ways of life, this action could bring detrimental rivalry between families in the regional culture. Neither Azad's nor Omed's love for Nazo has the potential of becoming a code that the community could be proud of. And so, love defined in the story is that it damages the practice of the millennia-old honor code, rituals, and traditions. As a result, Azad and Nazo consider migration to a foreign land.

When it comes to characters and what they stand for in this novel, their disposition represents the essence of a war-torn community. Azad, a newly assigned teacher gets captured by armed men soon after the home village is surrounded. The men of the village are as a rule taken as a group and shot down in summary executions. Both Omed and Azad get injured, but Azad suffers from critical injuries. Despite his injuries, Omed strives to rescue Azad and take him to safety; Azad fails to make it as later they are spotted by an armed night patrol and Azad gets killed. Nazo suffers in captivity, is oppressed by armed men, and recollects Azad as a prince charming. Azad's tragic ending symbolizes the tragic ending of the one-tenth of Yezidi people who failed to reach Shingal. Thus, I suggest that Gharbi Mustafa's characters in this novel portray the reality on the ground in areas invaded by members of armed forces. Most 
people in Shingal and its sub-districts got killed as a result of having retained their identity and faith throughout the ages and centuries.

By combining real and fictional events, Mustafa has creatively projected the tragic reality of the Yezidi people in his fictional novel in a way that has been unavailable in any other fictional medium so far. He has dedicated this novel to the circumstance of the Yezidi nation and the general attitudes of armed forces toward them, which is to say that the crucial mission of the author of What Comes with the Dust was to present the crimes committed against "the other," in this case, the minor native ethnic group inhabiting Shingal.

\section{Concluding Remarks Regarding Mustafa's First Two Novels}

The Kurdish novel is undergoing a good deal of experimentation, about which there is little consensus among critics. However, the Kurdish novel still has a long way ahead of it to reach maturity. There are some Kurdish novels that genuinely represent the essential of good prose. Gharbi Mustafa has written about the notion of coming of age in Kurdistan in his novel When Mountains Weep; readers can feel the author's interest in representing the harsh lifestyle of the Kurds in the modern age. While his second novel deals with atrocities committed by members of armed forces against Yezidi Kurds in Shingal, as a novel, it still shows artistic progress. There are some very frank scenes, which, however, for Kurdish readers, might prove offensive due to the seductive imagery. Such is the scene where Azad and Nazo are described as having engaged in sensual love "his lips sparked an earthquake inside her, and she clung to him. Lost in new sensations, she dug her nails into his shoulder blades as he pressed himself into her for the first time"(Mustafa, 2017, p. 7). Later on in the novel, it becomes apparent that she is enthralled not only with the sensual, but with sexual love per se: "She had stepped onto the forbidden path. Her feet sunk into the quicksand of illicit pleasure, and her soul fell into the claws of guilt. Yes, she had lost her virginity, her badge of honor, but did she still have her purity? Nazo wondered" (Mustafa, 2017, p. 9). This is an explicit reflection and an honest treatment of an incident taking place that has great influence on people's social decision-making process, yet little attention is paid to such events in other literary forms in Kurdish. The imagery drawn here can primarily be considered an initiative in representation of overt detail in the community where it is mostly suppressed by all available means.

The Kurdish novel moves forward at four levels. Firstly, it has become a realistic social novel as a text that deals with social issues. Secondly, it has reached levels that deal with important issues concerning local communities, issues that are embedded in the narrative of the text. Thirdly, it explicitly deals with psychological issues at the personal level. Moreover, it also has transformed aesthetically through the above three points combined.

\section{Badal's Novel: Oppression Leads to Internal Conflict}

But, does freedom from oppression lead to freedom from internal conflict? Dawiya Şervaneki [The End of a Warrior] (2005) written by the Iraqi Kurdish writer Ismat Muhammed Badal focuses primarily on two distinct decades: events which took place before the Kurdish National Uprising in Iraq in the spring of 1991 and the events that followed the uprising. 
Badal's novel is best analyzed through comparison with René Girard's psychoanalytic concepts regarding Don Quixote. Girard's essential concept is related to the nature of imitation, his main concern being the imitation of other "people's desire." In this regard, Girard has come up with two elements that contribute to the creation of desire in fictional characters and also, in real human beings. He notes:

If people imitate each other's desires, they may wind up desiring the very same things; and if they desire the same things, they may easily become rivals, as they reach for the same objects. Girard usually distinguishes 'imitation' from 'mimesis'. The former is usually understood as the positive aspect of reproducing someone else's behavior, whereas the latter usually implies the negative aspect of rivalry. It should also be mentioned that because the former usually is understood to refer to mimicry, Girard proposes the latter term to refer to the deeper, instinctive response that humans have to each other. (Andrade, p. Para.7)

The author goes on to distinguish two types of imitation, firstly the mimetic, which has a negative influence on the person longing for someone's desire. Girard mentions that with the mimetic, the subject does not necessarily want the other person's desire, but he wants to be that person, i.e. the subject longs to replace that person, which is impossible. This type of desire creates rivalry and leads to the creation of complexities for the person longing. In an extreme manifestation, it is called metaphysical desire, which again is unattainable. In Girard's terms, this desire is described as internal mediation.

The other type is imitation itself which is described by the author as external mediation. This type does not lead to rivalry and is usually productive. Gerard mentions this type as

the process in which a person influences the desires and preferences of another person. Thus, whenever a person's desire is imitated by someone else, they become a 'mediator' or 'model.' Girard points out that this is very evident in publicity and marketing techniques: whenever a product is promoted, some celebrity is used to 'mediate' consumers' desires: in a sense, the celebrity is inviting people to imitate him in his desire for the product. The product is not promoted on the basis of its inherent qualities, but simply because some celebrity desires it. (Andrade, p. Para 8)

The second type of longing for a mediator's desire is more acceptable as it does not create conflict in the subject having the desire of imitation. In the case of Dawiya Şervaneki, two distinct time frames represent these two types of triangular desire. The word triangle here, according to the author himself refers to the subject, the object, and the mediator. The subject is the person having the desire to imitate. Meanwhile, the object is the objective of the subject that he is yearning to acquire. And then the mediator is the person who triggers the sense of desire in his subject. When analyzing Don Quixote, the author states "in most works of fiction, the characters have desires which are simpler than Don Quixote's. There is no mediator, there is only the subject and the object"(Rivkin \& Ryan, 1998, p. 225). 
Dawiya Şervaneki, as a literary work highlights the protagonist's life experiences in a time of war and after the supposedly attained freedom from internal oppression of 1991. The novel reflects events related to Kurdish ethnicity during that period especially in terms of politics and social status. Despite to a great extent having achieved separation from the central Iraqi government, the population still undergoes hardship, and is dissatisfied with the new experience of local authority with its political corruption. The protagonist of the novel deprecates the status pro, because he, personally, has gained nothing from his veteran labor of years and is currently unemployed. His personal situation leads him to inner conflict, his attitude changing drastically from optimism to pessimism as regards both his own life and society. He becomes alienated from society and disconnected in his social relationships. He rejects his mother's insistence that he get married. The people around him such as his mother, sister, and his friends advise him to set aside his negative attitude. Finally, and at the very end of the novel he accepts his personal reality and reverts back to being the optimistic person he was.

Looking at the novel as a literary work, we see that in the opening chapter, the characters are appropriately introduced in order of importance - starting with the hero, Kovan, down to the flat character, Nazdar. The time and place are set forth, all events taking place in territorial Kurdistan. Badal, who also writes short stories, wrote his novel Dawiya Şervaneki in 2005, and it was published by the Kurdish Writers Union - Duhok. All in all there are twelve characters, both male and female. This work is considered to be in a special category as a novel of ideas. It considers certain aspects of living in context of when the novel was written. In this regard, as Arif Hito says in his book Roman xodîka Jiyanê, "the novel is the mirror of life and every reader can analyze it according to his opinion and his individual life experience" (Hi $\square$ to, 2011, p. 16). Badal tells us that after the Kurds' struggle against the Ba'ath regime, the Coalition Forces established the No-Fly Zone to ensure that the Iraqi regime would have limited influence in Kurdish areas - Iraqi sovereignty would be nominal and ceremonial. It thus seems that the author's intention behind writing this novel was to reflect on the political stance as well as the psychological state of the Kurdish people. Kovan, the protagonist of Badal's novel dedicates his whole life to seeking freedom and happiness for the Kurds, a mission he associates with the national cause. With the Kurds' measure of success due to the uprising, the question arises as to whether or not Kovan himself is on the way to happiness in accord with his former vision for the future? Let us turn to the text for an answer:

You could not know how dissatisfied I am with life. I'm lost. I followed a familiar path, one known to me. I was exhilerated treading that path. I didn't think about anything else. I enjoyed the company of friends. Although exhausted and suffering, I was nonetheless happy. I didn't have any psychological diseases. Now that euphoria has come to a halt since I see so much that I cannot accept. I had not an inkling of what would become of what I had envisaged (Badal, 2005, p. 79).

Kovan is unable to accept the ways of majority officialdom. They scarcely follow the path of a warrior, the principled fighter for a cause, one who struggles to bring about a revolution in 
the lives of his people. Eventually, Kovan blames himself for his dissatisfaction, and thinks his former struggle was a waste of time and effort. Therefore, he faces an inner conflict. All in all, the situation leaves him disappointed and grieving.

Injustices in local policy make Kovan suffer from loneliness and also create a negative turning point in his personal life "For what will you go home? It is the usual home, with long drawn-out nights. When do I rid myself of them? But, my mother, will my mother wait for me at the front door, and until I get back home" (Badal, 2005, p. 11). These words indicate that he is still consumed with longing, despite that the Kurds were granted a no-fly zone and had started to build their own governmental institutions. Instead of accepting the reality, Kovan becomes the victim of his metaphysical desire. This desire is emphasized by his being unable to obtain the status of an official position, such as he had envisaged before the uprising.

Kovan's father passed away in the mass emigration, and his sister had married, so he undertakes the responsibility for the household - but he is irresponsible. His mother is always alone alone in the house and wishes that her son would spend some time at home. He, however, routinely awakes in the morning, and goes out. He goes to the coffee shop where he spends time among older men, and listens to melancholy music, and sometimes walks the streets hoping to catch a glimpse of his lady-love; and, he always returns home late at night. His nightmares give him a sense of unease, and he wishes he could escape the ambiguities and ghosts that cast shadows over his life: "Such daily routines weaken one. House, city streets and coffee" (Badal, 2005, p. 10). Kovan's mother, his sister, and his friends push him to find work or at the least to return to engagement in politics. Such is the result of the failed metaphysical dream of his internal mediator.

The writer's use of platitudes effectively means that his novel lacks complex rounded actors, and in fact his characters are usually flat. Moreove, the narrative is weak in that the author's creative talent does not exclude the use of platitudes when writing about the community. Another defect of the narrative is unimaginative repetition that risks boring the reader, as when his mother repeatedly tells Kovan to get married: "Be quick, while I am alive, ask for the hand of a gentleman's daughter, and then, she starts to mention some familiar or maybe unfamiliar names of girls, girls in the neighborhood" (Badal, 2005, p. 18). Such ideas in Kurdish communities are a matter-of-course. Moreover, in typical Kurdish culture, whenever one suffers from psychological issues, family members immediately bring up the subject of marriage. This general attitude attitude towards marriage is common to families leading a traditional way of life, even with educated families. Kovan's mother continuously raises the subject of marriage, but Kovan's response shows no predisposition to marriage. He brushes aside his mother's advice; the destiny that he had anticipated and that is embedded in his dreams is to marry Viyan. This dream is in the realm of the nebulous, all-the-more-so since he does not know anything about her whereabouts. After the uprising, many villagers had moved away to cities, and others had even migrated abroad. As she is not to be found in the city, it could be assumed that she would probably be living abroad. Kovan, however, does not set aside his hope and is obsessed with the idea of finding Viyan. As a result of overthinking, living in the past, and reminiscing on the time he had with her, he becomes psychologically 
unstable, and any girl he runs into looks to him exactly like Viyan. The second major reason for Kovan's being deaf to his mother's wishes is that he is unemployed.

The story concludes with Kovan's sister, Nazdar, arguing that corruption is not uncommon life consists of both good and evil. She explains that when one sees corruption, it does not mean that all people are dishonest. These words have an affect on Kovan, and eventually, he decides to step out of his isolation and the depression that ruins his life. He looks for work and accepts his reality.

The story is told in the first-person, through flashbacks. However, the writer sometimes slips up and forgets that the story is from the viewpoint of his protagonist; he intervenes as the omniscient third person narrator - as for example with the dialogue: "While your mother poured out the tea, she said, I know you will leave me again, like those days when you left your parents and sister, and you went to the mountains without thinking how the government would treat us"(Badal, 2005, p. 34).

\section{A Further Look at the Protagonist's Internal Conflict}

Badal's hero had wished to live in a just society. The plot point of Act I is when Kovan does not accept the reality of the situation after the uprising of 1991 . He consequently suffers from a kind of inner conflict that literary criticism defines as the conflict between the character and his own goals:

An addition to the conflict between individuals, there may be the conflict of a protagonist against fate, or against the circumstances that stand between him and a goal ha has set himself; and in some works (as in Henry James'

Portrait of a Lady) the chief conflict is between opposing desires or values in the protagonist's own temperament (Abrams \& Harpham, 2009, p. 265).

The main reason behind Kovan's inner conflict is revealed to readers through situational irony which "occurs when incongruity appears between expectations of something to happen, and what actually happens instead. Thus, something entirely different happens from what the audience may be expecting, or the final outcome is opposite to what the audience is expecting" (Editor, 2018). The protagonist has fought against the Iraqi Baath regime for liberty and freedom, during which time his convictions clearly deepened. It came as a shock to him to see others who had fought alongside himself subsequently behave in a corrupt, even illegal manner. He took it as a personal affront when he saw that some who had collaborated with the Baath regime after the uprising were placed in responsible positions. His voiced concerns were not only ignored but had bad repurcussions for himself, and this isolated him from society. Feeling remorseful over his failure to protect his family, he left for the mountains to join the Peshmerga without even saying good-bye to his mother. This event created an inward dilemma that would re-appear ever afterwards. Above all, he should have had his mother's blessing! Without it, he would be liable to bad outcomes ever afterwards. The load of guilt is hard to bear, and the consequences seem to go on and on, when his father passes away, his sister marries, and his elderly mother is left at home alone. 
Moreover, when Kovan had departed to join the Peshmerga forces, he neither told his family, and nor did not tell his beloved Viyan: "Maybe this happened to you because of her. She offered you all her love and devotion. She loved you so much, then abruptly without any warnings you neglected her. Next, you joined the rebel forces" (Badal, 2005, p. 15).

Kovan in the depths of despair queries his connection to his motherland: "What makes you adhere to this ravaged land, don't you believe that all your hopes are dead and don't you get disappointed looking around" (Badal, 2005, p. 9). And so on and so on, his memories making his internal conflict ever more anachronistic. "Your room wall narrows, the ceiling caves in, you are in a grave, you become breathless. Your body is wet with sweat as you sleep; your pessimistic ideas, your confused mental state, become a ghastly specter. Shaken, you wake up"(Badal, 2005, p. 22).

His internal conflict is resolved by advice he receives, first of all, as said, from his sister Nazdar, then from his friend Karwan: "Do you have another option? When a good person gets separated from the caravan, it means you are giving a chance to a bad person. Kovan, unfortunately, I see that is your situation. Come, I will help you and your condition will improve" (Badal, 2005, p. 87). And, of course he receives kindly advice from others.

After one year of inner conflict, Kovan comes face to face with a huge gap in his life. He asks himself whether or not a psychologist would help. Then one day, he earnestly seeks to discover his real self: "You stood in front of the mirror, and you looked at yourself. You thought that you have not looked at yourself for a very long time, although you stand in front of the mirror everyday. You always brush your hair and dash outside. Today you are looking at yourself differently, as if seeing yourself for the first time" (Badal, 2005, p. 64). Eventually, Kovan's internal conflict is resolved - apparently due to his visits to Karwan's office, Nazdar's kind words, and finally his getting married.

\section{Reflection of Marginalization and Colonization in Yashar Kemal's Novel of 1982}

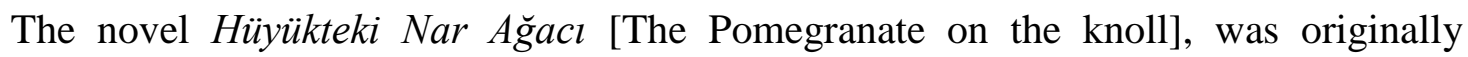
published in 1982 in Turkish Language. But the Kurdish edition [Dara Hinarê] is used in this article which was translated and published in 2005. This novel is the story of five Kurdish men, Memet, Hosik, Yusif, Ashiq Ali, and Memet the kid, who travel to Chukurova when there is a famine in their own region. They are in search of work, food, and money. However, on arrival they find that Chukurova has an abundance of machinery, notably tractors. As a result, many farmers, peasants, and laborers have lost their jobs. Consequently, the five men suffer from degradation, longing, unemployment, hunger, pessimism, disease, and poverty.

Chukurova no longer enjoyed a smooth running cooperative social set-up. Chieftains fired peasants from their farms since machinery lessened the need for labor. Even nature had somehow changed, and the climate in Chukurova was getting warmer; mosquitoes swarmed everywhere. The five men in expectation of the usual fair-minded treatment come to the realization that the people of Chukurova are not the same. Disappointed, they decide to head 
back home, when a woman suggests that they visit a certain holy pomegranate tree. The pomegranate tree is reputed to offer solutions to problems, and make their dreams come true. Hopeful and believing, they set out to find that very tree.

They head for Anvarza. A villager greets them, whip in hand, and asks if they are mountaineers. He orders them to leave their village immediately. He calls out "long live tractors, combine harvesters, and marshals." Offended, they feel that what they had faced in Chukurova was less painful.

Then, Memet, Hosik, Yusif, Ashiq Ali, and Memet the kid find a charming farm, full of trees, and flowers. Even the birds, snakes, and flies head for that farm. They arrive at the village where Ahmed, one of the villagers receives them warmly and respectfully. To their surprise Ahmed offers them food. Hosik, one of the five, takes out his dagger to cut up the melons. Memet the kid stares at the dagger. Hosik claims that it belonged to his father who had fought in the Sariqamish war against Russia and had taken it from the pocket of a dead Russian soldier.

Ahmed, the villager, did not know the whereabouts of the pomegranate tree, but he said he knew someone called Hassan who could guide them to it. Hassan was a sage whose work was to heal the sick with natural remedies. To that end, he always went to the mountains to fetch plants; he was familiar with most kinds of plants, trees, and rivers. They told Hassan about their dire situation, but he sadly said that there was no holy tree now in Chukurova, and if there were he would know of it. He went on to say that once Chukurova had been full of beautiful holy trees, but that people had cut them down. Once more, disappointed, they departed.

Hassan had related that one Muslim's khalifa, Ali bin Abu-Talib, had passed by the pomegranate tree, and the tree had cried out to Ali bin Abu-Talib. He had asked and prayed to God to bless the pomegranate tree and asked the tree to show mercy and bless people in need of help.

Finally, the five men found what had been the pomegranate tree! It had died, and only a log was there. Even so, rejoicing, they gathered around the tree's log and they prayed. Only Memet the kid did not pray, saying that since the pomegranate tree had died, it could not bless anyone. Hosik, for whom the tree was most holy, warned Memet the kid in this regard, saying that the tree could probably take vengeance. They told the pomegranate tree about their wishes, dreams, and troubles. Next morning, they discovered that Memet the kid had taken Hosik's dagger and left. Later in the day, they decided to go back home to Duladul mountain. There, they found that nothing had changed, and they felt betrayed.

A way of life full of traditions lurks in the background of the narrative, stepping into the foreground to play a role not only to motivate the actions of characters, but also as a sort of guardian for the morality of the writer's novel. There is an assumption that traditions may protect a man's dignity and guide him even in our modern times, and that people suffer and deeply feel the loss of their traditions. Indeed, the writer of the novel wishes to say that when 
the traditional way of life recedes and becomes less important in guiding an individual's life, he is more likely to face hardships, and even his survival may become a struggle.

The era of agricultural society had changed and was replaced by the industrial. The human social fabric and established connections were no longer valued, and the society depended on machines for their productivity. To again transform man's psychology would involve eliminating the machines.

\section{Ecological Dimensions}

In his novel, Yashar Kemal also reflects on the importance of trees to the environment. The tree could be considered as a memory of the passage of time. When we upset the balance in nature with changes in our sources for industry, we put even the climate at risk. The search of the five men for the pomegranite tree signifies hope for the ecological future of the world, and, Kemal wants to say, destroying and losing that future will be catastrophic. Kemal quite clearly states that if destruction of nature continues, we shall first witness the death of nature, then the end of man:

There were many holy trees in Chukurova. Chukurova was a forest of pomegranate trees, around the long way to the sea. During spring and summer times, these trees would be covered with red blossoms, so that the whole area from here to Ayas would all be red and would move just like sea waves. Black snakes used to mate under the red blossoms, turning as red as the iron in a fire. Now there is not one tree left on the plain, and they uprooted all the trees. Now, neither pomegranate nor oak, nor pine, not one tree grows in Chukurova, not one solitary one. Not a single holy thing remains on this plain, not to mention the pomegranate tree (1982, p. 139).

The hopes and dreams of Kemal's characters are in keeping with their innate spirituality. They feel deeply, their passions are unruly, their grudges abound. And, whereas the five heroes cling to hope when they undertake their wishful journey, they still depend on something deeper in pursuing their dreams. Hopes and dreams are an essential part of the outlook of men who search for a better life. Moreover, their search for the pomegranate tree reveals their purity of heart. They do not bear the mark of corruption as do the majority population in Chukurova.

Every nation has its own traditions. Regardless of whether traditions are transmitted orally or written down, they are reflected in every aspect of life, social life, religious life, politics, and literature. Traditions bind us to our forefathers and make one nation distinct from another. Some of the best moments in our personal lives, Kemal wants to say, are when we keep ageold traditions of family, clan, and country. Society's heroes may on occasion have laid down their lives for the sake of noble traditions. Comparable to the pursuit of scientific knowledge, the traditional path is considered to be a true and valid approach to life - but with an assured outcome without the need for experimentation. Traditions not only influence social institutions such as family, clan, law, religion, and art, but also enter into our conversations 
and mold our characters. The traditional and virtuous way of life guides us and saves us from the many pitfalls and dangers in life, and ultimate leads to happiness and progress.

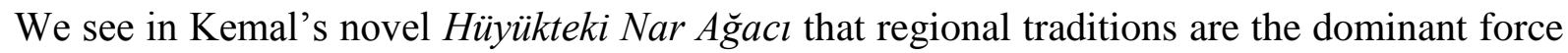
behind his characters' journey. Man's search for tradition is an affirmative theme in most of Yashar Kemal's works. Worthy of note is that the author himself witnessed the transition of Turkish and Kurdish regional culture from the agricultural to the industrial, and also how the life-style in villages changed after that. And, it seems that the author's personal experience stayed with him and drove him to reflect on the conflict between traditional values and the perceived need for dynamic industrialization. In Hüyükteki Nar A $\breve{g} a c l$ the traditional way of life finds expression in artforms, the spoken language, social life, and the behavioral patterns of individuals.

Traditional arts are represented through music and specifically in the form of minstrels and bards. Ashiq Eli, an outstanding folksinger, expresses his sorrows, miseries, love, pain, and patriotism, love of nature, friendship, and grief for the poverty-stricken by singing folksongs.

\section{Traditional laboring}

Our novel holds traditional laboring in high esteem, as an intrinsic aspect of farming and in general the agrarian way of life, which is seen as the essence of our livelihood. Kemal's novel is rich in images on how the tools of farming are used, tools such as bulls, oxen, horses, plows and scythe, and animals used in harvesting wheat, and rice. The importance of both men and women is in terms of how they contribute to rural life. So, we see Kemal's five major protagonists as guardians for all the above, and in their capacity as guardians they search for that which is in the process of diminishing.

\section{Traditional Music and Songs}

Even in the modern era, music for the Kurds remains highly politicized. They have not yet established an independent country where music can grow and deal with other issues other than patriotism. According to Baqi

They put song and rhythm into the same category as Water, Fire, Air, and Earth, which have all important roles in organizing nature's formations. Great prophets such as David (Dawood), Zoroaster (Zartosht) and some great musicians from ancient societies have used music as a tool and coordinator for their heralding and for their rituals. Since many famous notables (Zoroaster and so on ....) were born and arose from [the territory of] Kurdistan, and the good news spread to other places, and the land of the Kurds was in the vicinity of the Babylonian and Ilam civilizations -

Kurdistan should be regarded as the birthplace and the home of song and music" (Baqi, 2001, p. 246).

Baqi states that since Zoroastrians, Yazidis, and Ahlu-Haque were aware of the effect of music, they used songs and instrumentation in their rituals and ceremonies; for the reading of 
scripture such as the zoroastrian Gathas, Yarsan of Ahlu-Haque, and Jewlah-u-Mashafa Resh of Ezidian, they used folk tunes with emphasis on rhythm: "All [extant] documentation shows that Yezidi religious [ritual] emphasizes the oral” (Spät, 2008, p. 31). It may be assumed then that ancient religious ritual provided Kurds with a musical background.

Accordingly, Kurdish folk music functions as a protector and a guardian of Kurdish culture, literature, and identity. Despite all the internal conflicts, and external occupations and wars in Kurdistan throughout its history, over and above historical, geographical, and dialectical distinctions, there remains a sense of connection and understanding that binds the Kurdish nation together - at least greatly due to traditional narratives and folksongs and music.

Kurdish songs have many variants such as the "Hayrans, Lawiks, Siyaw Chamanah, Horah, Chamar, Beyt, Payizoks, Band, Narinks, and Diloks. There are also love songs, along with dances and music for weddings"(Baqi, 2001, p. 245). However, traditionally there are only three types of classical performance: storytelling (çirokbêji); minstrels (stranbêji); and, bards (dengbêji). They stage their performances mainly at night gatherings (şevbêri), especially in winter; perhaps since winters last for about four months, the people of the villages like to gather round nights to listen to storytellers and bards. The history of Kurdish music is regarded as the beginning of Kurdish literature as well.

\section{Oral Literature}

Yashar Kemal's works are enriched by his use of Kurdish and Turkish oral literature. One may assume that it was his intention to lean on Kurdish oral literature in his literary works, and in any case, he relies on oral traditions stemming from the singing of the dengbêji (bards).

Dengbêj is a Kurdish compound word consisting of deng (voice), and bêj (to tell). If you add the suffix " $i$ " dengbêji, we have "the man whose voice relates." Kemal says that the "dengbêji is a man who recites epics in a professional way"(Scalbert-Yücel, 2009). Roger Lescot, the first Western scholar to research Kurdish oral literature defines dengbêji as follows:

These professional poets, who over the years furbished their memories as apprentice of certain old masters, assumed the task of being conversant with the traditions of the past and, if some new events were to occur, the celebration of the heroic deeds of the present. ... They sometimes confronted each other in competitions held regularly until quite recently. Every emir or chief of any vital tribe maintained one or more of these bards, whose song, due to contemporary allusions might at times have political connotation. Thanks to their unlimited repertoire and their matchless gift of improvisation, the dengbêji transmitted poems with thousands of verses, from the remotest centuries until today (1977:798).

Yashar Kemal pictures the dengbêji in Ashiq Ali's songs as being characterized by patience, hope, kindness, and generosity, and the blessing of their having wonderful voices. He sees the effectiveness of the dengbêji's song as being due to the playing of the tambour and singing in a heartfelt manner. He mentions that 
Ashiq Ali would start out his song which is a form of storytelling in Kurdish culture. His songs were about love, illness, and hard living conditions. As did the dengbeji, Ashiq Ali would sometimes sing about nature, and imaginary things. Kemal writes:

Ashiq Eli was passionate, standing or sitting, he sang on the sadness of love, pain, death, poverty, cancer, children, fever, loneliness, and on Kizlmaks, Ceyhan, Seyhan, Chukurova, bugs, damned motors, the dangerous world, mountains covered with snow, and flocks of deer. He sang to the aghas about injustice, until sunrise, and the arrival of dawn's fresh air. Then Ashiq Eli would put down his tambour (1982, p. 55).

Ashiq Ali is described as singing songs on various occasions that would create an optimistic mood in his companions and gift them a lift, in the spiritual sense. He would also allude to stories of famous religious figures in antipication that this might serve as a sort of psychological treatment.

Ashiq Eli holds his tambour. He sings about headsprings, highways, longing, and injustice. He narrates that each mosquito is like a wolf. Ashiq Ali states that God, who rescued Yusuf, will look at our faces and save us. He used to sing songs about the pomegranate tree: There are red roses with fresh water, [sparkling] lights beneath the pomegranate tree. Until morning Ashiq Eli would sing imaginary tales about the pomegranate tree (Kemal, 1982, p. 92).

Kemal in his novel Hüyükteki Nar Ağacı shows that the dengbêji tradition is deeply rooted in Kurdish society: "Sometimes you can find two or even three or all of a family's sons as dengbêji, Memet patiently explains. This is Ashiq Ali, Ashiq Hussein's son. He is known in all the plains and mountains. His grandfather was called Ashiq Khalid, their names are well-known in Avshar. His father is the great Dadaloghlu. His family belongs to the Dadaloghlu family" (Kemal, 1982, p. 106).

We see that the art of the dengbêji includes both singing songs and telling stories, as when Ashiq Ali tells a love story about a boy who was very poor.

Ashiq Eli narrated: there was a poor boy that fell in love with a rich man's daughter. The girl's father rejected him. He asked the boy to give him two thousand liras $[\ldots]$. The boy could not pay the father because he was penniless. The boy and the girl decided to run away to Chukurova [...]. They left, fleeing at nighttime. One day, the boy went to bring some food, alone $[\ldots]$ He returned late. The girl had been in hiding. Then he discovered that the girl had been bitten and eaten alive by mosquitoes. The boy found only his bride's bones [...]. The boy went crazy. He always wept and narrated his sad story to every passerby (Kemal, 1982, pp. 53-54-55).

Contrary to the notion that the dengbêji performs only vocally and without playing any musical instruments, Kemal's Hüyükteki Nar A ğacı informs us that the dengbêji traditionally 
used the musical instruments, saz and tambour. These instruments were thought to make their songs more pleasurable for their audiences.

The dengbêji are mostly thought of as traveling from place to place, since they have used their art as a way to make money in times of harsh economic conditions. In Kemal's novel, the five heroes when they return to Chukurova, go hungry and have nothing to eat. Then they start to sing Ashiq Ali's songs and play the tambour. The people gather round. Enjoying Ashiq Ali's songs, they give money. So, had it not been for Ashiq Ali and his songs, our heroes would probably have suffered most cruelly from hunger.

Laboring is considered as basic in life, the traditional manner of work leaving its imprint on the personality: "A man with his wife, and two daughters who were twelve years old were collecting hay $[\ldots]$ their faces were covered with dust $[. .$.$] the wife with her two daughters,$ were putting hay in place" (Kemal, 1982, p. 45).

Another traditional skill is mentioned, which is that of a healer. The healer (hakim) was liked and respected. The Kurds trusted their methods of healing since they relied on and used only natural herbs and medicines extracted from nature and considered as sacred. They had a comprehensive knowledge of herbs, roses, trees, and plants. And they, like the bards, came from traditional families who passed on their skills to their own family members.

\section{References}

Abrams, M. H., \& Harpham, Geoffrey Galt. (2009). A glossary of literary terms (9th ed.). Boston: Wadsworth Cengage Learning.

Andrade, Gabriel. René Girard. In Internet Encyclopedia of Philosophy.

Aristotle. (2019). The Art of Rhetoric. Harvard University Press: Penguin Books.

Badal, Ismat Muhammad. (2005). Dawîya Şervanekî. Duhok: Kurdish Writers Union.

Baqi, Muhammad. (2001). The History of Kurdish Music. 2018 Edition: Literary Devices.

Gibbs, Raymond W. and Colston, Herbert L. (2007). Irony in Language and Thought: A Cognitive Science Reader. New York: Lawrence Erlbaum Associates.

Hîto, Arif. (2011). Roman Xodîka Jiyanê (Çapa 1. ed.). Duhok Kurdistan, Iraq: Ji Weșanên Eketiya Nivîserên Kurd.

Kemal, Yashar. (2005). Dara Hinarê (Firat Jewary \& Sami Alhaj, Trans.). Hewler: Education Publishing House.

Mustafa, Gharbi. (2013). When Mountains Weep: Coming of Age in Kurdistan: CreateSpace Independent Publishing Platform. 
Mustafa, Gharbi. (2017). What Comes with the Dust Goes with the Wind. Peacock, 98.

Rivkin, Julie, \& Ryan, Michael. (1998). Literary theory, an anthology. Malden, Massachusetts: Blackwell.

Scalbert-Yücel, Clémence. (2009). The Invention of a Tradition: Diyarbakır's Dengbêj Project. European Journal of Turkish Studies, 10.

Spät, Eszter. (2008). Late Antique Literary Motifs in Yezidi Oral Tradition: The Yezidi Myth of Adam. Journal of the American Oriental Society, 128(4), pp. 663-679.

Uzun, Mehmed. (2003). Diyarbakir: The Slap in the face. The International Journal of Kurdish Studies, 17(2), p. 25.

Uzun, Mehmed. (2007). Mirina kalekĩ rind (1. baskı. ed.). Kadıköy, Istanbul: Ithaki. 